\section{PKM PENYULUHAN \\ INTERNET SEHAT DI SMK TELKOM PEKANBARU}

\author{
Triono Dul Hakim', Vita Amelia ${ }^{2}$, \\ Winda Monika ${ }^{3}$ \\ 1,2,3)Universitas Lancang Kuning \\ *Vita Amelia \\ Email: vita.amelia@unilak.ac.id
}

\begin{abstract}
Corona Virus 19 has changed the way educational systems work from offline to entirely dependent online. This has been affecting the students to access the Internet more often than usual. Inevitably, the students could access the Internet at any time and anywhere for study purposes. Internet literacy is highly needed to be applied in the school to increase student awareness of the adverse effects of the Internet, such as Internet addiction, accessing porn, and so on. The general problem faced by our partner is the school is a vocational school that focuses on IT, therefore during or out of the pandemic covid 19, students are exposed to use the Internet more than another school.

Furthermore, this school has students ranging from 16 to 18 , which is psychologically unstable. We did a workshop about healthy use of the Internet and examined the dependency of the students on the ard Internet. Our activity shows that the student's understanding and awareness toward the healthy use of Internet increased significantly and most of students realized that they should be able to control the use of the Internet to make their life balance.

Keywords: the healthy use of the Internet; education; Corona Virus 19; teenager; vocational school
\end{abstract}

\begin{abstract}
Abstrak
Transformasi pembelajaran dimasa pandemic Covid19 merubah pelaksanaan pendidikan dari yang biasanya berlangsung secara tatap muka atau luring menjadi bergantung pada jaringan Internet yaitu daring. Pembelajaran daring menjadikan siswa leluasa mengakses Internet kapan pun dan di mana pun. Edukasi terkait literasi teknologi dalam hal ini penggunaan Internet sehat atau tepat guna sangat penting agar dampak negatif seperti kecanduan Internet, mengakses konten pornografi, dan lain sebagainya dapat dihindari. Permasalahan umum pihak mitra ialah mitra merupakan Sekolah Menengah Kejuruan (SMK) bidang telekomunikasi yang focus mempelajari penerapan teknologi informasi sehingga diluar masa pandemic pun tetap bergantung menggunakan Internet sebagai fasilitas penunjang pembelajaran. Selain itu, SMK mitra memiliki siswa kategori remaja dengan rentang usia 16-18 tahun yang secara psikologis cukup rentan terpengaruh hal-hal baru. Adapun metode pelaksanaan kegiatan ialah berupa penyuluhan kepada siswa terkait Internet sehat dan pengujian tingkat ketergantungan penggunaan Internet siswa. Hasil kegiatan menujukkan perubahan pemahaman yang cukup signitfikan dari cukup paham menjadi paham akan Internet sehat dan siswa semakin menyadari bahwa penggunaan Internet perlu dikontrol.
\end{abstract}

Kata Kunci: Internet sehat; Pendidikan; Pandemi; Remaja; SMK 


\section{PENDAHULUAN}

Perkembangan teknologi Internet begitu pesat dan telah begitu memasyarakat. Internet merupakan jejaring atau alat yang digunakan untuk mempermudah tiap orang untuk berinteraksi di dunia maya dalam artikata penggunaannya mampu menjembatani komunikasi lintas jarak dan waktu. Seriring perkembangannya, penggunaan Internet tidak dapat dipungkiri memberikan kemudahan, optimasi dan efektifitas dikehidupan masyarakat. Saat ini Internet diaplikasikan diberbagai aspek kehidupan manusia seperti pada sektor pendidikan, bisnis, administrasi pemerintaan dan lain sebagainya. Internet kini hadir diberbagai pelosok belahan dunia sehingga menghadirkan perubahan tatanan kehidupan di masyarakat. Dengan kemudahan yang dihadirkan Internet, hal ini menjadikan pengguna Internet terus bertambah tiap waktunya. Berdasarkan survey yang dilakukan oleh Asosiasi Penyelenggara Jasa Internet Indonesia (APJII) mengungkapkan bahwa terdapat sebanyak 196,7 juta jiwa pengguna Internet aktif di Indonesia saat ini dengan penetrasi Internet selama tahun 2019 - 2020 yaitu sebesar 73,7\% dan pertumbuhan jumlah pengguna Internet sebesar 8,9\% (APJII, 2020).

Ibarat dua sisi mata pedang, Internet merupakan suatu alat yang perlu dikendalikan. Banyak penelitian menunjukkan bahwa penggunaan Internet yang tepat atau sehat dapat meningkatkan kepuasan hidup, kesejahteraan dan penghargaan terhadap diri sendiri (Çikrıkci, 20I6). Internet Sehat adalah suatu program dari Kementerian Komunikasi dan Informatika Indonesia (Kemkominfo), Republik Indonesia yang bertujuan untuk memberikan pemahaman penggunaan Internet secara sehat dan aman dengan menanamkan pengetahuan terkait etika penggunaan Internet (Hidayanto, 2015). Dalam pembelajaran Internet sehat, pemaparan konsep teoritis merujuk pada kemampuan literasi digital. Literasi digital adalah pemahaman dan kemampuan seseorang tidak hanya dalam menggunakan perangkat lunak atau mengoperasikan perangkat digital, tapi juga mencakup berbagai macam keterampilan kognitif, motorik, sosiologis, dan emosional yang kompleks, yang dibutuhkan pengguna agar dapat berfungsi secara efektif dalam lingkungan digital. Literasi digital mencakup kemampuan memahami instruksi "membaca" dari tampilan grafis di antarmuka pengguna; memanfaatkan reproduksi digital untuk menciptakan materi baru yang bermakna dari materi yang sudah ada; membangun pengetahuan dari navigasi hipertekstual nonlinier (hypertextual navigation); mengevaluasi kualitas dan validitas informasi; dan memiliki pemahaman yang matang dan realistis tentang "aturan" yang berlaku di dunia maya (Y. Eshet and Y. Eshet, 2004).

Sebaliknya, penggunaan Internet tidak tepat atau tidak sehat seperti penggunaan secara berlebihan hingga menjadi kecanduan berpengaruh buruk terhadap kondisi psikologis (user's 
psychological well-being) dan keterampilan sosial pengguna (S.Valenti, 2009) (R.Larose, 200I). Tidak hanya itu, kriminalitas marak terjadi di Internet melalui social media yang mengancam remaja seperti pornografi, bullying, target ancamanan, penghinaan, memata-matai, dan lain sebagainya (D.U.Patton, 2019). Tentunya fenomena penggunaan Internet tidak sehat ini mengancam kondisi fisik dan metal terutama anak-anak sebagai objek yang rentan kecanduan Internet, mudah mengakses pornografi, cyber bullying dan lain sebagainya. Dari data jumlah pengguna Internet saat ini di Indonesia, 80\% diantaranya merupakan remaja dengan rentang usia I5-19 tahun (Miniwattss, 2020)(Miniwatts, 2020). Persentase anak usia sekolah di Indonesia pada tahun 2017 yang mengalami kecanduan Internet dalam hal bermain Game Online adalah 10,15\% (Jap, Tiatri, Jaya, \& Suteja, 2013). Game online patut diwaspadai sebab berdasarkan beberapa penelitian menunjukkan bahwa game online mempengaruhi penurunan motivasi dan hasil belajar siswa (Theresia, Setiawati, \& Sudiadnyani, 2019). Disamping itu, kecanduan game online juga mengakibatkan terjadinya perubahan psikologis berupa perubahan sikap siswa menjadi agresif dan brutal (Setiawati \& Gunado, 2019).

Sejak merebaknya virus severe acute respiratory syndrome coronavirus 2 (SARS-CoV-2) atau dikenal dengan covid 19, pada tahun ajaran baru bulan Juli 2020, Kementrian Pendidikan dan Kebudayaan melakukan transformasi kegiatan pembelajaran dari luring menjadi daring. Hal ini menjadi tantangan tersendiri bagi pihak sekolah, siswa, dan orang tua siswa dimana diperlukan persiapan berupa kesiapan infrastruktur Internet, pengetahuan menggunakan alat teknologi komunikasi, dan lain sebagainya (P. Wahono, 2020). Disamping itu, siswa menjadi dibiasakan mengakses Internet lebih sering dibanding sebelumnya dalam menggunakan alat seperti smartphone atau laptop dalam kegiatan pembelajaran.

Hadirnya Internet dalam kegiatan pembelajaran siswa menimbulkan kekhawatiran tersendiri. Diperlukannya pembekalan kepada guru, siswa, dan orang tua berupa literasi Internet sehat sehingga penggunaan Internet tepat guna. Disamping itu, orang tua perlu melakukan pengawasan secara berkala untuk memantau aktifitas siswa selama menggunakan Internet di rumah dikarenakan siswa berada dalam usia perkembangan yang secara psikologis cukup rentan terpengaruh hal-hal baru. Hurlok seorang pakar psikologi membagi tingkat perkembangan anak dimana kategori remaja adalah individu yang berada pada rentangan umur antara 13 sampai 21 tahun, awal masa remaja dimulai dari umur 13 tahun sampai 16 atau 17 tahun dan akhir masa remaja berawal dari 17 tahun sampai 18 tahun (Hurlock, 1980). Masa remaja dihadapkan pada perkembangan kebutuhan untuk beradaptasi dengan perubahan fisik, sosial, dan psikologis, dimana pada masa ini remaja menghadapi proses pencarian identitas diri serta membentuk 
hubungan. (Santrock, 1998). Di era globalisasi saat ini remaja dihadapkan pada kemajuan teknologi informasi dimana dituntut untuk mampu beradaptasi dengan baik. Ketidak mampuan remaja dalam beradaptasi dengan penggunaan teknologi informasi dalam hal ini penggunaan Internet dapat berakibat pada tidak sesuainya perkembangan remaja dengan tugas-tugas perkembangannya. Oleh karena itu, keterampilan Internet sehat di lingkungan sekolah sangat diperlukan.

Berdasarkan latar belakang di atas, kami melakukan penyuluhan Internet sehat. Adapun mitra kami dikegiatan Pengabdian Pada Masyarakat (P2M) ini adalah Sekolah Menengah Kejuruan (SMK) Telkom. SMK Telkom memiliki siswa berjumlah 443 siswa, 12 jurusan, 64 guru dan 22 kelas (terdiri dari kelas VII, VIII dan IX). Berdasarkan analisa di lapangan, SMK Telkom dipilih sebagai mitra dikarenakan memiliki siswa dengan rentang usia 15-19 tahun sehingga secara psikologis rentan terpengaruh dampak negatif penggunaan Internet. Selain itu SMK ini berbasis Teknologi Informasi dimana tingkat penggunaan Internet dikalangan siswa dan guru cukup tinggi dibanding sekolah lain baik di luar masa pandemic maupun dimasa pandemic saat ini. Adapun tujuan dari penyuluhan ini yaitu memberikan pemahaman dan penguatan tentang Internet dan manfaatnya; ancaman atau resiko penggunaan Internet; kecanduan Internet dikalangan remaja; ciri-ciri kecanduan Internet; dan upaya mengatasi kecanduan Internet.

\section{METODE PENGABDIAN}

Adapun metode pelaksanaan kegiatan ini ialah ceramah dimana tatap muka langsung di SMK Telkom Pekanbaru oleh dosen yang tergabung dalam tim dengan peserta pelatihan dengan tetap memperhatikan protokoler kesehatan.

Prosedur kerja yang akan dilaksanakan antara lain.

I) Tahap persiapan, difokuskan dengan menyiapkan semua peralatan yang dibutuhkan untuk melaksanan kegiatan ini, studi literatur dan melakukan koordinasi dengan instansi terkait untuk melakukan kegiatan.

2) Perancangan materi dan penyebaran modul pembelajaran. Adapun materi yang akan diberikan mencakup:

a. Pengertian Internet sehat

b. Dampak positif dan negatif dari Internet

c. Kemampuan literasi digital menggunakan model empowerment 8 yaitu kemampuan mengidentifikasi, mengeksplorasi, menyeleksi, mengorganisasi, Membuat/Menciptakan, mempresentasi, menilai dan menerapkan informasi digital yang diperoleh dari Internet

3) Pelaksanaan kegiatan berupa penyebaran pre-test, penyampaian materi oleh dosen 
yang tergabung di dalam tim, dan evaluasi akhir berupa penyebaran post-test.

\section{PELAKSANAAN DAN PEMBAHASAN}

Kegiatan penyuluhan bertempat di SMK Telkom Pekanbaru. Target peserta awal yaitu mencakup siswa, guru, dan wali murid. Dikarenakan protokoler kesehatan selama pandemic yang mengharuskan untuk jaga jarak, sehingga tidak memungkinkan kegiatan penyuluhan diikuti oleh guru dan wali murid. Selain itu, sekolah menerapkan aturan selama pandemic diantaranya sekolah dibuka namun diberlakukan jadwal bergilir sehingga tiap siswa hanya datang ke sekolah dua hari dalam seminggu dan jumlah siswa di tiap kelas yang hadir hanya setengahnya. Adapun jumlah siswa yang mengikuti penyuluhan yaitu sebanyak 23 siswa yang terdiri atas 20 siswa perempuan dan 3 siswa laki-laki. Berdasarkan pengakuan siswa, rata-rata menggunakan Internet selama 8-10 jam sehari. Sebagian besar menggunakan Internet untuk mengakses social media yaitu Facebook (100\%), Instagram (86,9\%), dan Tiktok (50\%). Mereka dengan gambling mengakui bahwa sudah cukup bergantung dengan Internet dan cukup resah apabila tidak terkoneksi dengan Internet beberapa saat.

Pada tahapan pertama, tim melakukan tanya jawab sederhana sembari membagikan dan menunggu siswa menjawab kuesioner pre-test yang dibuat di Google Form. Waktu yang diberikan kepada siswa untuk menjawab kuesioner pre-test yaitu lebih kurang 5 menit. Selanjutnya, tim menjelaskan terkait tujuan, maksud diadakannya penyuluhan, dan menjelaskan materi tentang “Internet sehat sebagai bagian dari literasi digital kepada siswa SMK”.

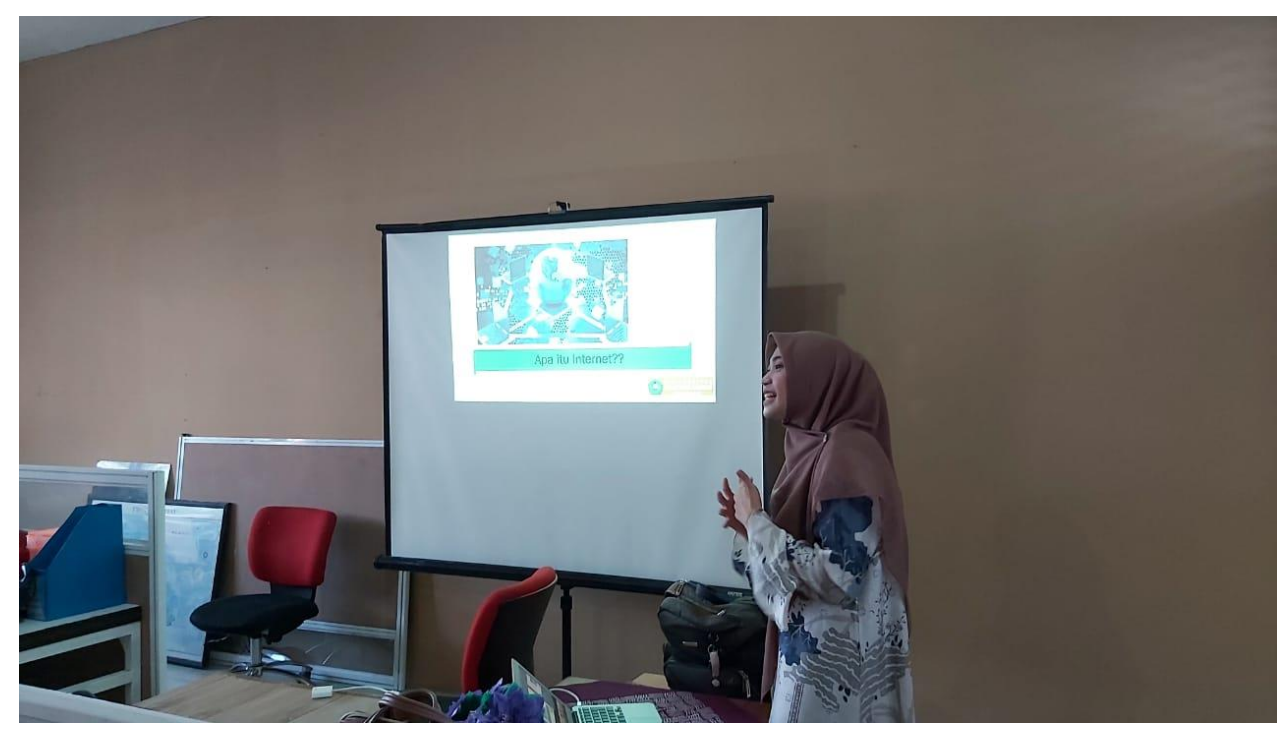

Penyapaian materi tentang Internet sehat 
Siswa terlihat antusias mengikuti penyuluhan terutama saat dijelaskan terkait ciri-ciri kecanduan Internet dan bahaya kecanduan Internet. Setelah pemaparan materi, dilakukan tanya jawab selama lebih kurang 15 menit. Tanya jawab berlangsung cukup menarik, sebagian besar siswa merasa bahwa ciri-ciri kecanduan sudah hampir ada didiri mereka sehingga perlu mengontrol penggunaan Internet sehari-hari. Tahap terakhir dilakukan evaluasi berupa penyebaran kuesioner post-test untuk melihat sejauh mana pemahaman siswa terhadap materi yang dipaparkan. Sama halnya dengan pre-test, post-test berlangsung selama 5 menit.

Pre-test dan post-test menggunakan skala likert dengan rincian yaitu sangat paham (5), paham (4), cukup paham (3), tidak paham (2), dan sangat tidak paham (I). Berdasarkan jawaban siswa dari pengisian pre-test dan post-test didapat data seperti terlihat di Tabel I.

Tabel I. Hasil pre-test dan post-test

\begin{tabular}{|c|c|c|c|c|c|c|}
\hline Item Pertanyaan & \multicolumn{5}{|c|}{ Skala Likert } & \multirow[t]{2}{*}{ Rata-rate } \\
\hline Pre-Test & 5 & 4 & 3 & 2 & $\mathrm{I}$ & \\
\hline $\begin{array}{l}\text { Anda mengetahui dan } \\
\text { memahami tentang Internet }\end{array}$ & $\begin{array}{c}10 \\
(43.5 \%)\end{array}$ & $\begin{array}{c}5 \\
(21.7 \%)\end{array}$ & $\begin{array}{c}7 \\
(30.4 \%)\end{array}$ & $\begin{array}{c}1 \\
(4.3 \%)\end{array}$ & 0 & 4.0 \\
\hline $\begin{array}{l}\text { Anda mengetahui dan } \\
\text { memahami tentang Internet } \\
\text { sehat }\end{array}$ & $\begin{array}{c}8 \\
(34.8 \%)\end{array}$ & $\begin{array}{c}3 \\
(13.0 \%)\end{array}$ & $\begin{array}{c}7 \\
(30.4 \%)\end{array}$ & $\begin{array}{c}1 \\
(4.3 \%)\end{array}$ & $\begin{array}{c}4 \\
(17.4 \%)\end{array}$ & 3.4 \\
\hline $\begin{array}{l}\text { Anda mengetahui tentang } \\
\text { manfaat Internet }\end{array}$ & $\begin{array}{c}10 \\
(43.5 \%)\end{array}$ & $\begin{array}{c}8 \\
(34.8 \%)\end{array}$ & $\begin{array}{c}4 \\
(17.4 \%)\end{array}$ & $\begin{array}{c}1 \\
(4.3 \%)\end{array}$ & 0 & 4.2 \\
\hline $\begin{array}{l}\text { Anda mengetahui tentang } \\
\text { ancaman atau resiko } \\
\text { penggunaan Internet }\end{array}$ & $\begin{array}{c}12 \\
(52.2 \%)\end{array}$ & $\begin{array}{c}5 \\
(21.7 \%)\end{array}$ & $\begin{array}{c}5 \\
(21.7 \%)\end{array}$ & 0 & $\begin{array}{c}1 \\
(4.3 \%)\end{array}$ & 4.2 \\
\hline $\begin{array}{l}\text { Anda mengetahui mengapa } \\
\text { remaja rentan kecanduan } \\
\text { Internet }\end{array}$ & $\begin{array}{c}\text { II } \\
(47.8 \%)\end{array}$ & $\begin{array}{c}6 \\
(26.1 \%)\end{array}$ & $\begin{array}{c}5 \\
(21.7 \%)\end{array}$ & $\begin{array}{c}1 \\
(4.3 \%)\end{array}$ & 0 & 4.2 \\
\hline $\begin{array}{l}\text { Anda mengetahui apa itu } \\
\text { kecanduan Internet }\end{array}$ & $\begin{array}{c}7 \\
(30.4 \%)\end{array}$ & $\begin{array}{c}8 \\
(34.8 \%)\end{array}$ & $\begin{array}{c}6 \\
(26.1 \%)\end{array}$ & $\begin{array}{c}1 \\
(4.3 \%)\end{array}$ & $\begin{array}{c}1 \\
(4.3 \%)\end{array}$ & 3.8 \\
\hline $\begin{array}{l}\text { Anda mengetahui ciri-ciri } \\
\text { kecanduan Internet }\end{array}$ & $\begin{array}{c}7 \\
(30.4 \%)\end{array}$ & $\begin{array}{c}9 \\
(39.1 \%)\end{array}$ & $\begin{array}{c}6 \\
(26.1 \%)\end{array}$ & 0 & $\begin{array}{c} \\
(4.3 \%)\end{array}$ & 3.9 \\
\hline $\begin{array}{l}\text { Anda mengetahui cara } \\
\text { mengatasi kecanduan Internet }\end{array}$ & $\begin{array}{c}5 \\
(21.7 \%)\end{array}$ & $\begin{array}{c}9 \\
(39.1 \%)\end{array}$ & $\begin{array}{c}8 \\
(34.8 \%)\end{array}$ & 0 & $\begin{array}{c}1 \\
(4.3 \%)\end{array}$ & 3.7 \\
\hline Post-Test & & & & & & \\
\hline
\end{tabular}




\begin{tabular}{|c|c|c|c|c|c|c|}
\hline $\begin{array}{l}\text { Anda mengetahui dan } \\
\text { memahami tentang Internet }\end{array}$ & $\begin{array}{c}9 \\
(39.1 \%)\end{array}$ & $\begin{array}{c}\text { I I } \\
(47.8 \%)\end{array}$ & $\begin{array}{c}3 \\
(13.0 \%)\end{array}$ & 0 & 0 & 4.3 \\
\hline $\begin{array}{l}\text { Anda mengetahui dan } \\
\text { memahami tentang Internet } \\
\text { sehat }\end{array}$ & $\begin{array}{c}10 \\
(43.5 \%)\end{array}$ & $\begin{array}{c}3 \\
(56.5 \%)\end{array}$ & 0 & 0 & 0 & 4.4 \\
\hline $\begin{array}{l}\text { Anda mengetahui tentang } \\
\text { manfaat Internet }\end{array}$ & $\begin{array}{c}14 \\
(60.9 \%)\end{array}$ & $\begin{array}{c}9 \\
(39.1 \%)\end{array}$ & 0 & 0 & 0 & 4.6 \\
\hline $\begin{array}{l}\text { Anda mengetahui tentang } \\
\text { ancaman atau resiko } \\
\text { penggunaan Internet }\end{array}$ & $\begin{array}{c}12 \\
(52.2 \%)\end{array}$ & $\begin{array}{c}10 \\
(43.5 \%)\end{array}$ & I (4.3\%) & 0 & 0 & 4.5 \\
\hline $\begin{array}{l}\text { Anda mengetahui mengapa } \\
\text { remaja rentan kecanduan } \\
\text { Internet }\end{array}$ & $\begin{array}{c}12 \\
(52.2 \%)\end{array}$ & $\begin{array}{c}9 \\
(39.1 \%)\end{array}$ & I (4.3\%) & $\begin{array}{c}1 \\
(4.3 \%)\end{array}$ & 0 & 4.4 \\
\hline $\begin{array}{l}\text { Anda mengetahui apa itu } \\
\text { kecanduan Internet }\end{array}$ & $\begin{array}{c}9 \\
(39.1 \%)\end{array}$ & $\begin{array}{c}13 \\
(56.5 \%)\end{array}$ & I (4.3\%) & 0 & 0 & 4.3 \\
\hline $\begin{array}{l}\text { Anda mengetahui ciri-ciri } \\
\text { kecanduan Internet }\end{array}$ & $\begin{array}{c}15 \\
(65.2 \%)\end{array}$ & $\begin{array}{c}6 \\
(26.1 \%)\end{array}$ & $2(8.7 \%)$ & 0 & 0 & 4.6 \\
\hline $\begin{array}{l}\text { Anda mengetahui cara } \\
\text { mengatasi kecanduan Internet }\end{array}$ & $\begin{array}{c}13 \\
(56.5 \%)\end{array}$ & $\begin{array}{c}9 \\
(39.1 \%)\end{array}$ & 0 & I (4.3) & 0 & 4.5 \\
\hline
\end{tabular}

Dari 8 item pertanyaan yang diberikan kepada siswa, pada Tabel I terlihat perbedaan peningkatan rata-rata dari hasil pre-test dan post-test. Hasil post-test mengalami peningkatan pemahaman dari keseluruhan item pertanyaan. Beberapa item yang mengalami kenaikan yang cukup signifikan diantaranya yaitu pemahaman siswa tentang Internet sehat (rata-rata pretest=3.4, rata-rata post-test $=4.4$ ) dari cukup paham menjadi paham, pemahaman siswa terhadap kecanduan Internet (rata-rata pre-test=3.8, rata-rata post-test $=4.3$ ) dari cukup paham menjadi paham, pemahaman siswa terhadap ciri-ciri kecanduan Internet (rata-rata pre-test=3.9, rata-rata post-test=4.6) dari cukup paham menjadi paham, dan pemahaman siswa terhadap cara mengatasi kecanduan Internet (rata-rata pre-test=3.7, rata-rata post-test=4.5) dari cukup paham menjadi paham.

Berdasarkan pemaparan siswa saat diskusi berlangsung, beberapa dari siswa memanfaatkan internet sebagai sarana mereka menyalurkan hobbi yaitu salah satunya dengan berjualan online dengan memanfaatkan social media yang mereka miliki. Sebagian besar dari mereka sangat mengetahui ancaman atau resiko penggunaan Internet, mereka mengungkapkan bahwa mereka 
terkadang tidur tidak sesuai jam yang seharusnya, sehingga waktu istirahat berkurang karena terus terhubung dengan Internet. Di samping menyadari bahwa penggunaan Internet dapat berdampak negatif, siswa juga tidak bisa terlalu jauh dari Internet karena seluruh sumber belajar saat ini dengan mudah diakses di Internet. Mereka mengungkapkan bahwa jika ada pertanyaan terkait pelajaran, maka Internet menjadi tempat bertanya pertama kali sebelum mereka membaca buku pelajaran. Selain itu, sebagian besar siswa mengatakan bahwa pandemic menjadikan salah satu faktor mereka terhubung dengan Internet dalam waktu yang cukup lama.

Siswa juga memaparkan bahwa akses Internet begitu mudah di dapatkan saat ini. Tidak ada kekhawatiran akan habisnya paket karena selain pemerintah memberikan bantuan paket, toko yang menyediakan pulsa Internet juga banyak. Selain itu, mereka tidak ketakutan tidak dapat mengakses Internet karena jaringan Internet di kota Pekanbaru cukup memadai.

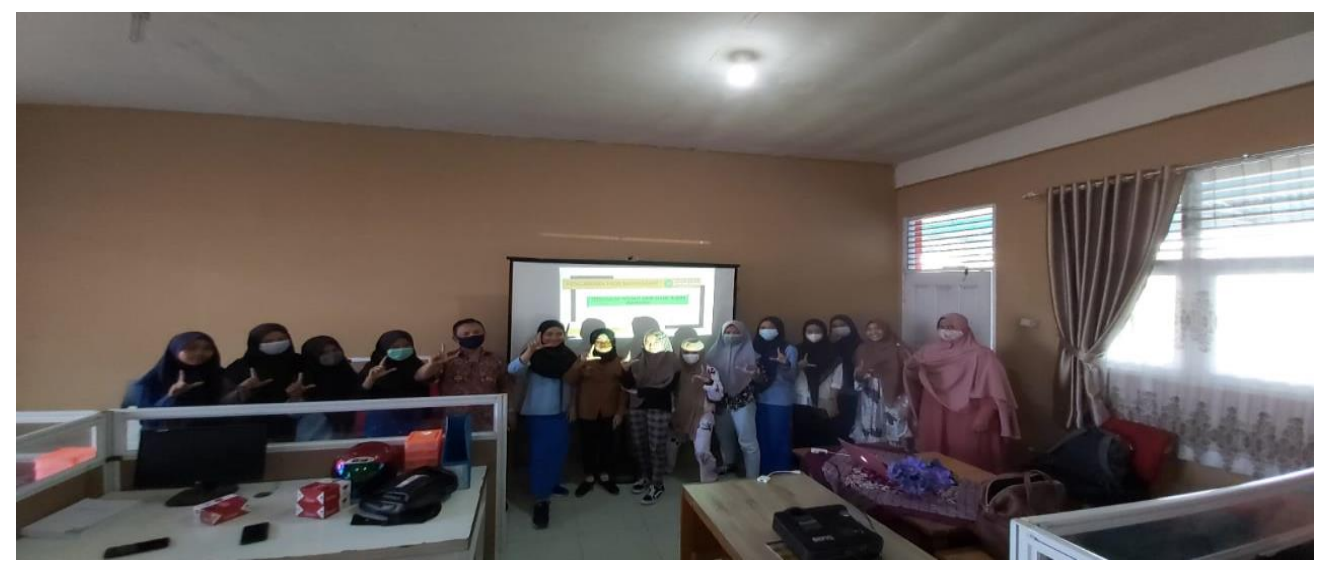

Foto bersama setelah kegiatan

\section{KESIMPULAN DAN SARAN}

Berdasarkan rangkaian kegiatan penyuluhan dapat disimpulkan bahwa terjadi kenaikan dan penguatan pemahaman siswa tentang Internet dan manfaatnya; ancaman atau resiko penggunaan Internet; kecanduan Internet dikalangan remaja; ciri-ciri kecanduan Internet; dan upaya mengatasi kecanduan Internet. Terlihat siswa begitu antusias dan aktif dalam berdiskusi selama penyuluhan berlangsung. Setelah pelatihan ini dilaksanakan diharapkan:

I) Agar siswa dapat mengontrol penggunaan Internet dengan secara bijak membagi waktu dalam pemanfaatan teknologi, khususnya penggunaan Internet.

2) Pandemic menjadikan siswa begitu dekat dengan smartphone dan Internet, sehingga ke depan diperlukan strategi pembelajaran yang baik dari pihak sekolah untuk dapat 
mengontrol perilaku pencarian dan penggunaan Informasi siswa yang telah telah mengalami pergeseran

3) Literasi Internet perlu dimasukkan dalam muatan materi pembelajaran di sekolah sebagai upaya dari pihak sekolah untuk mengedukasi siswa agar terhindar dari dampak buruk penggunaan Internet.

\section{UCAPAN TERIMA KASIH}

Atas terlaksananya kegiatan pengabdian masyarakat ini, kami mengucapkan terimakasih kepada mitra, Kepala Sekolah SMK Telkom Pekanbaru dan Fakultas Ilmu Budaya Universitas Lancang Kuning Pekanbaru.

\section{DAFTAR PUSTAKA}

APJII. (2020). Laporan Survei Internet APJII 2019 - 2020. Asosiasi Penyelenggara Jasa Internet Indonesia, 2020, I-I46. Retrieved from https://apjii.or.id/survei

Hidayanto, F. (2015). Pentingnya Internet Sehat. Asian Journal of Innovation and Entrepreneurship, 4(0I), 2I-24.

Hurlock, E. B. (1980). Psikologi perkembangan. Jakarta: Erlangga.

Jap, T., Tiatri, S., Jaya, E. S., \& Suteja, M. S. (20I3). The development of Indonesian online game addiction questionnaire. PloS One, 8(4), e61098.

Miniwatts, M. G. (2020). Asia Internet Usage Stats Facebook and 2020 Population Statistics. Internet World Stats. Retrieved from https://www.internetworldstats.com/stats3.htm

Santrock, J. W. (1998). Life-Span Development, 5th. Brown Communications. Inc.

Setiawati, O. R., \& Gunado, A. (2019). PERILAKU AGRESIF PADA SISWA SMP YANG BERMAIN GAME ONLINE. Jurnal Psikologi Malahayati, I(I).

Theresia, E., Setiawati, O. R., \& Sudiadnyani, N. P. (2019). Hubungan kecanduan bermain game online dengan motivasi belajar pada siswa SMP di kota Bandar Lampung tahun 2019. PSYCHE: Jurnal Psikologi, I (2), 96-104. 